Alieva G. Aladdinovna ${ }^{1}$

Russian university of economics

name of G.V. Plekhanov
ORIGINAL SCIENTIFIC ARTICLE doi:10.5937/ekonomika1602015A

Received: March 29, 2016

Accepted: April 27, 2016

\title{
CORRELATION BETWEEN CORRUPTION AND ECONOMIC CRIMES IN HOUSING AND COMMUNAL SERVICES
}

\begin{abstract}
In this article it is argued that the correlation between crimes committed in one of the most important sectors of the Russian economy - the housing sector. Along with this, the author reasons that the government allocated large sums of money attract criminal gangs in housing and communal services that, in turn, contributes to the Commission along with economic and corruption crimes.
\end{abstract}

Key words: housing and communal services, corruption crimes, economic crimes, anti-corruption efforts, bribery, corruption bribery, legalization and money-laundering.

JEL classification: K10, K14

\section{КОРЕЛАЦИЈА ИЗМЕЪУ КОРУПЦИЈЕ И ПРИВРЕДНОГ КРИМИНАЛА У СТАМБЕНИМ И КОМУНАЛНИМ СЛУЖБАМА}

\section{Апстракт}

У овом научном раду аргументује се корелациона веза међу свриеним инкриминачијама у једној од важних грана руске економике - стамбено-комуналној сфери. Упоредо с тим, ауторка доказује, да крупне новчане суме издвојене из бучета државе привлаче криминалне групе у стамбено-комуналну привреду, ито, посебно доприноси извршавању реда економксих и корупџионих инкриминащија.

Кључне речи: стамбено-комунална привреда, корупџионе инкриминације, економске инкриминације, антикорупциона делатност, подмићивање, корупцุиони мито, легализација, прање новца.

\section{Introduction}

Counteraction of corruption in housing and communal services (hereinafter HCS) is one of the priority activities of the relevant divisions of the Ministry of internal Affairs of the Russian Federation (hereinafter - the MIA of Russia). In particular, as noted by the head of Department on fight against corruption GUEB and PC of the MIA

\footnotetext{
${ }^{1}$ alieva.ga@rea.ru
} 
of Russia, A. Y. Ryabtsev, special attention is paid to the suppression of illegal activity of officials, to identify corrupt links between officials of the authorities and representatives of commercial organizations operating in the housing sector ${ }^{2}$.

The development of new industries and economic institutions and economic activities of the state, formation of new economic relations and technologies of document management and registration of financial-economic activity, substantial effect on the activity of the investigative units for the disclosure and investigation of economic and corruption crimes.

\section{Corruption and economic crimes in housing and communal services}

Clear evidence of the scale of corruption offenses in housing and, therefore, a public response to this issue is the consolidation of the Decree of the President of the Russian Federation from 11.04.2014 № 226 “About the national anti-corruption plan for 2014 - 2015 years" of top-priority goals:

- handling of the issue of the fight against corruption in the housing sector at the meetings of the Presidium of the presidential Council of the Russian Federation on corruption counteraction;

- conducting audits of state Corporation "Fund of assistance to reforming of housing and communal services";

- conducting inspections of implementation of legislation on combating corruption in the housing sector;

- $\quad$ prevention of corruption crimes and their control in the housing sector through the housing sector of the complex of educational and educational measures to clarify responsibility for crimes of corruption;

- prevention of corruption crimes and their control in the housing sector by conducting complex investigative actions and operational-search activities (hereinafter referred to as ORM) for the detection and suppression of bribery and mediation in bribery in the housing sector;

- $\quad$ analysis of corruption risks in the housing sector ${ }^{3}$.

Of the normative legal act it can be concluded that housing is an important component in the livelihoods of citizens, affecting almost the entire population of the country and, therefore, occupies an exceptional position in a number of other sectors of the economy.

It is necessary to consider that according to experts in the budgets of commercial structures are laid for about $50 \%$ of the costs for bribing officials at various levels . However, as one of the most important directions of development of our country in modern socio-legal and economic conditions, efforts to suppress offences of corruption and economic in the sphere of housing and communal services, as well as their disclosure and an objective investigation does not give positive results that is a result of the absence of methodical provision of the activity of investigation departments.

While the crimes in housing and communal services there is no official statistics and, as a rule, the development of methodical recommendations on disclosing and 
investigation of crimes should be investigated to use mainly internal information. In the statistics of the Main information-analytical center of the Ministry of internal Affairs of Russia (further - the MIAC Ministry of internal Affairs of Russia) from 2010 to 2011 there is no count on information concerning corruption crimes in housing and communal services. However, economic crimes for the period identified 276, 435 thousand and 202, 454 thousand, respectively. With 2012 enter the details of corruption cases, amounting to 49, 513 thousand of all registered crimes. On the website of the General Prosecutor's office noted that during the same period last year registered a 40, 407 thousand corruption crimes. In 2013 this index equals 42, 506 thousand, while in 2014 - 32, 204 thousand .

Analyzing the data of the RF IC, the number of previously investigated corruption offences in housing and communal services for 2009 is 210 criminal cases, 2010 - 152, 2011 - 377, 2012 - 565, 2013 - 567, $2014-658$, there is an increase in the detection of acts of corruption in the study area.

Thus, referring to figures registered money laundering, we note them not matching the real crime of this type, given the latency, which reaches $95 \%{ }^{4}$. In the Russian Federation annually, several hundred thousand economic crimes, which include crimes in housing and communal services. Of them tens of thousands of crimes associated with obtaining criminal income in large or especially large size (in 2010 - 51, 969, 2011 - 40, $315,2012,36,083,2013-29,878$, in 201425,422 ), which causes their connection with "money laundering". From the point of view of criminology is quite remarkable is that according to experts, corruption have more than half exposed to the RF criminal groups 5 . In 2010 on criminal cases about corruption set the damage for the sum more than 12 billion rubles. In 2012 takes into account the damage from corruption crimes in Russia amounted to almost 21 billion rubles. Financial losses from unfair officials in 2013, compared to 2012, increased by 5 billion rubles, and if you calculate the damage directed to the court claim requirement, he was 32,7 billion. rubles, exceeding the indicator of 2012 by RUB 11 billion $^{6}$.

Analysis of information about the damage from crimes in the sphere of housing and communal services officially underway since 2012 For the specified period of time the damage from these crimes amounted to 1 billion 193, 509 million rubles, in $2013-3$ billion 571, 748 million rubles, in 2014 - 4 billion 648, 326 million rubles. Analysis of these statistical data allow to conclude that criminal violations in the housing sector began to occur in relation to large sums of money, which allows to establish correlations between economic and corruption crimes in this sphere. The problems associated with investigating and establishing the loss on them, we believe, contribute to the distortion of statistics that does not fully reflect the actual damage caused by these offences.

In addition, given that the crime of corruption in utilities is often identified as a result of investigation of criminal cases about plunders in this sphere of economic activity, as well as the peculiarities of the subject of a criminal assault, which is cash in the form of "kickbacks" received from grants, subsidies and other benefits, which explains their close connection with fraud and theft.

Also it should be clarified that the relationship of bribery and commercial bribery in utilities theft, fraudulent legalization (laundering) of funds, etc., determines the content of a significant amount of financial, accounting and other documents in criminal cases of the given group of crimes, without which, sometimes, committing them is impossible. This is due primarily to the fact that annually by the state for the development of utilities 
allocated (in billion rubles): 2009 - 142, 2; 2010, 223, 2; 2011 - 216, 5; 2012, 136, 0; 2013 - 104, 2; 2014, 144, 5; $2015-118,0^{7}$. Expenditures from the Federal budget on the maintenance of housing and communal services for 2010 amount to 234, 9 billion rubles., 2011 - 279, 6 bln. RUB., 2012 - 475, 7 billion RUR , 2013 - 177, 6 billion rubles, 2014, 119, 6 billion rubles. in addition, subject and additional funding from governments, consumers and housing organizations: financial, stock, investment and other resources.

The significant turnover of funds in the housing sector attracts criminals and their organized groups. This leads to the Commission of offences in respect of subsidies from Federal and municipal budgets, which are determined on the basis of the approved Federal standards to cover the losses of the housing and utilities sector. In the framework of the Housing programme the total funding for 2011 - 2015 was 462, 26 billion rubles , in 2012 - 2015. the Fund of assistance to reforming of housing and communal services is provided from the Federal budget of 217 billion rubles.

According to the research Foundation "INDEM" the risk of corruption in economic relations in the housing sector is $32 \%$, i.e. almost one third of citizens in housing and communal services is subject to corrupt influence. The volume of the corruption market in this area, i.e. the amount of money spent by citizens a year on bribes of housing and communal service, is 22,7 million dollars - twelfth the rate of sixteen possible. These data allow to draw a conclusion that is small in comparison with other spheres of interaction between citizens and the authorities of bribes to utilities when their widespread distribution leads to a significant spread of bribery and bribery.

However, despite a complex system of legislative regulation of legal relations in the housing sector, in most municipalities it operates according to the scheme, the main element of which is a diversified municipal housing and utility enterprise, integrating the functions of the owner of housing and utilities infrastructure of the customer on execution of works on repair and maintenance of housing communal property and contractor. This contributes to the development of corruption, and comprehensive schemes of withdrawal of money from the housing sector and, respectively, the number of crimes of economic orientation.

Shows studied investigative practice, between the municipal company and contractors formed economic and criminal scheme due to lack of control over their activities on the level of outsourcing.

Contractors and subcontractors, pass a bribe and illegal remuneration of persons performing managerial functions in a commercial organization or municipal companies for the conclusion with them contracts on performance of works or rendering of services, signing of acts of acceptance and other documents necessary for the transfer to the accounts of their organizations cash to ensure a win in the competition for government contracts in the housing sector, etc. Further, obtained from Federal or regional budget for the trust funds transferred by usetcpnodelay and receiving illegal remuneration in affiliates for alleged work performed or services rendered.

For example, the materials of the criminal case, which implies that the Deputy chief of Department housing and communal services of the Perm city administration B. received a bribe from the contractor in the form of money in the amount of 1 million 300 thousand rubles for the signing of contracts for the equity financing of capital repair of common property in several apartment houses in Perm and the allocation of budgetary funds of the HOA, with whom the contractor had been awarded the contract agreements for the conduct of such work ${ }^{8}$. 
The head of noncommercial partnership "housing Control" B. was detained when receiving unlawful remuneration in the amount of 10 thousand rubles from the representative of one of the utility companies in Miass for defending the interests of the latter in the administration of the city ${ }^{9}$.

From the materials of the criminal case investigated by the investigative Committee of the Russian Federation across the Kaliningrad region, it is clear that the head of Department on reforming of housing and communal services of city administration of Sovetsk P. was detained when receiving through the intermediary of a bribe in the amount of 250 thousand rubles from the Director of a commercial organization for the coordination and transfer certificates and certificates of the executed works on major repairs of the roof and facade of two apartment houses in Sovetsk ${ }^{10}$.

Examined the investigative practices allows to identify one typical scheme of criminal activity in the housing sector, where local governments passed bribes to representatives of housing and communal services of regions and their subordinate units at regional and local levels for the allocation of Federal or regional budget funds for the development of housing in a particular region.

In this case, the correlation of corruption and economic crimes in housing and communal services observed the following: due to organizational and technical capacities of municipal enterprises are not able to function and exercise at the same time its activity in all three sectors of housing without the involvement of third parties, which lays the basis for committing the specified crimes from the past. These are the organization for the maintenance and repair of housing Fund, housing and utility companies (utility), the organization of diversified utilities. Management companies, housing cooperatives (hereinafter - LCD), housing cooperatives (further - ZHSK) and homeowners Association (hereafter HOA) are also included in the composition of housing organizations ${ }^{11}$.

Along with the above, we believe it is important to note the following. The author of this article study found that housing provides the reproduction and maintenance of housing by providing the following housing services, where for the provision of officials and persons performing managerial functions in commercial and other organizations operating in the housing sector, receiving bribes and illegal remuneration:

1. By granting use of premises under the contract of social hiring or the contract of hiring of premises the state or municipal housing stock;

2. For maintenance and repair of the dwelling, including rooms and the apartment building management, maintenance and current repairs of common property in an apartment house;

3. On capital repair of common property in an apartment house proprietors of premises in an apartment house;

4. For the collection and removal of solid waste;

5. For the collection and removal of liquid waste from residential buildings ;

6. Maintenance of elevators;

7. Cleaning of common areas and surrounding area;

8. Improvement of housing and adjacent territories;

9. Providing information and communication services, including television antennas and Internet providers, etc. 
For residential services refers to "actions or activities of the contractor to maintain and restore the proper technical and sanitary condition of buildings, structures, equipment, communications and facilities of housing and public utilities, waste removal and supply to the consumers of electric energy, drinking water, gas, heat and hot water." 12

Are these services between enterprises of the housing stock (state unitary enterprise (hereinafter - GUP), public institution (hereinafter - the civil code), legal entities (a limited liability company (hereinafter LLC); joint stock company (hereinafter - JSC), etc.), etc.) and the consumers of these services, i.e. the owners of premises in apartment houses. On behalf of the latter, in most cases, are managing companies (hereinafter CC), HOA or LCD that shows studied investigative practice, working with companies housing often form an organized criminal group.

Through bribery and giving bribes to representatives of law enforcement bodies and bodies of local self - government of UK, TSZH, ZHK and performers of housing services to draw up bogus contracts on performance of works and (or) rendering of services implement their activities without obtaining licenses and other permits, using firms-lived or non-existent commercial organization to transfer funds to their personal account.

So, the Director of the MUP “Inzensky heating” L, his Deputy V., M. V. and subordinates, using the documents of fictitious companies, organized crimes on the implementation of fuel, which they had extracted an income of over 7 million rubles To cover the activity of L. contributed to the transfer of the law enforcement officer monetary reward for not taking measures to stop their criminal activities, for which he was arrested ${ }^{13}$.

The example also serves as a criminal case, investigated in relation to the General Director of state unitary enterprise RM "Association of road service stations and autostations" A., who had illegally received from the Director of "SMP "Turetskoe" money in the amount of 63 thousand rubles. for the transfer of the last temporary possession and use of nonresidential premises ${ }^{14}$.

Considering the criminal activities in the housing sector, one of the links of which is the criminal code, we note that the Housing code of the Russian Federation ${ }^{15}$ establishes three main ways to manage the multifamily house:

1. The direct management of proprietors of premises in an apartment house;

2. The management of the HOA or LCD or other specialized consumer cooperative;

3. The managing organization (managing company).

These methods of apartment building management are included in the housing organizations and the most common of these is asset management. The attractiveness of this method to commit bribery and commercial bribery in utilities is a result of the complexity of implementation of control over the activities of penal code of the state and the public, legislative gaps, the interest for illicit enrichment and impunity for crimes in this sphere.

The result of these actions management companies are the lack of hot water, heating and electricity in the winter, leaking roofs, breakthroughs pipelines, pollution of territory of apartment houses and etc. the head of the presidential administration noted that causes such effects is "the lack of professionalism and indiscipline management companies, and not without a banal theft"16. 
Thus, the existence of complex and multilevel patterns of legal regulation of housing sector, a large volume of legal institutions that regulate relationships in this field, contributes to the difficulties of the investigator in determining the rules of economic behavior on the market of housing and communal services. However, not clarified in the wording of fundamental concepts; legal regulation of the studied areas is also carried out normativelegal acts that are not directly industry sector: tax, land, employment legislation, etc. These circumstances predetermine the challenges in investigative units in the investigation of criminal cases on crimes in the sphere of housing and communal services.

It should be noted that, despite a complex system of legislative regulation of legal relations in the housing sector, in most municipalities it operates according to the scheme, the main element of which is a diversified municipal housing and utility enterprise, integrating the functions of the owner of housing and utilities infrastructure of the customer on execution of works on repair and maintenance of housing communal property and contractor-contractor.

When the detection and investigation of criminal cases on crimes in the study area, the investigator should know what the activity of the municipal enterprise can implement on the three leading industries of housing, which are:

- housing construction;

- housing;

- utilities.

It is necessary to clarify that these enterprises are not able to function and exercise at the same time its activity in all three sectors of housing without the involvement of third parties. The housing organizations are the organization for the maintenance and repair of housing Fund, housing and utility companies (utility), the organization of diversified utilities. Management companies, housing cooperatives (hereinafter - LCD), housing cooperatives (further - ZHSK) and homeowners Association (hereafter HOA) are also included in the composition of housing organizations . Given this information, the investigator at the stage of preliminary check of messages on crimes in the sphere of housing and communal services is authorized to request necessary information from these organizations, as well as to receive from the officers explanation.

Housing construction, which targets residential building intended for human habitation, provides a redistribution of housing facilities and that they create housing and services. The main component of the investigated areas is the housing market, which implements the functions of reproduction of the housing Fund, i.e. the construction, modernization and reconstruction of housing, which is the basis of housing. In turn, this market cannot function without serving its housing and public services, where the bulk of criminal assault. In this regard, in the thesis to be examined only the data of HCS (housing and communal services).

Investigative practice shows, because of the lack of information about the structure of housing and communal services, bodies and organizations operating in this sector of the economy, in the modeling process mental picture of an event criminal event, the investigator faces a number of difficulties. In this regard, we believe it is necessary to outline the structure of housing and communal services (on the branches), the housing and communal services, to indicate their types, to describe the structure of the organs, organizations providing these services in the study area. 
Thus, housing provides the reproduction and maintenance of housing by providing the following housing services:

- granting use of premises under the contract of social hiring or the contract of hiring of premises the state or municipal housing stock;

- maintenance and repair of the dwelling, including rooms and the apartment building management, maintenance and current repairs of common property in an apartment house;

- capital repair of common property in an apartment house of proprietors of premises in an apartment house;

- collection and removal of solid waste;

- $\quad$ collection and removal of liquid waste from residential buildings ;

- maintenance of lifts;

- cleaning of common areas and surrounding area;

- $\quad$ improvement of housing and adjacent territories;

- providing information and communication services, including television antennas and Internet providers, etc.

For residential services refers to "actions or activities of the contractor to maintain and restore the proper technical and sanitary condition of buildings, structures, equipment, communications and facilities of housing and public utilities, waste removal and supply to the consumers of electric energy, drinking water, gas, heat and hot water."17 Are these services among enterprises of housing and the consumers of these services, i.e. the owners of premises in apartment houses. On behalf of the latter, in most cases, are management companies, TSZH or housing. However, it should be noted that the Housing code of the Russian Federation establishes three main ways to manage the multifamily house:

1. the direct management of proprietors of premises in an apartment house;

2. the management of the HOA or LCD or other specialized consumer cooperative;

3. the managing organization.

These methods of apartment building management are included in the housing organizations and the most common of these is the managing organization. The attractiveness of this method for the implementation of bribery and commercial bribery in utilities is due to the extremely low control of the state and the public over the activities of organizations of housing and communal services, high interest in the enrichment and impunity of officials for crimes in the sphere of legislative omission.

So, in the absence of the decision of owners of premises in an apartment house on the choice of the method of apartment building management, the local authority should conduct an open tender to select a managing organization. The owners of the premises in this case are obliged to conclude the contract of management of apartment home chosen by the contest management organization for a period of not less than one year. This provision of the Housing code of the Russian Federation allows officials and persons performing managerial functions in commercial or other organization, to engage in criminal collusion for selfish purposes. As the investigative practice shows, for a certain remuneration the offender in connection with his official position in the interests of the managing organization contributes to the winning of tenders for the right of conclusion of the contract on management of apartment building, public 
contracts on accomplishment of adjoining territories, the implementation of capital repairs of apartment houses and signs acts of acceptance of work performed, other Executive documents.

Here is a typical example of the materials of the criminal case opened in KhantyMansi Autonomous district in respect of the Deputy head of the urban settlement, Parking lot construction, capital repair, housing, land and property relations B., on signs of the crime provided by part 3 of article 30, paragraph "b," including 5 senior 290 of the criminal code. It is established that in August of 2012. the administration of the urban settlement Talinka conducted an open tender for the right to conclude municipal contracts for capital repair of apartment houses, the winner of which is recognized as one of the organization of the settlement. B., head of the Commission on carrying out of the competition, offered his protection and lobbying of interests of the company to conclude contracts in the territory of the urban settlement and also illegally demanded from the company of the transfer of funds in the amount of 800 thousand rubles as compensation for already concluded contracts. In addition, B. explained that in case of refusal to fulfil its requirements, the completion certificate will not be signed and as a result, the company will not be listed cash for work performed, in connection with which management has addressed in law enforcement bodies. After receiving part of a bribe in the amount of 400 thousand rubles., B. was detained by police ${ }^{18}$.

In turn, utilities provides production and finishing to the direct consumers of public services, which include:

- $\quad$ service cold and hot water supply;

- water removal (Sewerage) and wastewater treatment;

- electricity;

- $\quad$ gas supply (including deliveries of household gas in cylinders);

- heating (a heat supply, including deliveries of firm fuel in the presence of furnace heating);

- the collection, transportation and disposal of household waste.

Under utilities is "the activity by serving customers of any utility resource individually, or 2 or more of them in any combination to ensure favorable and safe conditions of use of residential, non-residential premises, the common property in an apartment building and land and located on them dwelling-houses (households)"19.

Investigative practice shows that management companies, as intermediaries between owners of premises in apartment buildings and utilities providers do not pay the last money received from the owners on payment of municipal services, kidnap and resell fuel, and so eventually leads to the formation of debts to utilities providers and poor delivery of public services.

An example is the criminal case brought by investigative management of UMVD of Russia across the Tver region against the head and the employee of one of management companies of Tver on the fact of causing of property damage done by the supplier organization. According to investigators, the men in the period from 2011 to 2014 abusing the trust caused the property damage done by the supplier and the enterprise for the sum more than 26 million rubles. Using a controlled company with similar names, located at one and the same legal address, the defendants received from tenants cash houses for heat supply services. However, money in a resource-supplying organization would not be transferred, and disposed of them at his discretion. 
An example of theft of fuel resources can serve as prosecution, the investigative part of the SU of UMVD of Russia across Khabarovsk territory, from which it follows that in the period from August to October 2011, two founders of company "D." of Komsomolsk-on-Amur has created an organized community and developed the scheme of illegal activity in the housing sector. The organization consisted of four groups. Some engaged exclusively in the theft of oil. Other - transport and sales of stolen oil. To this end, we used one-day firms, the activity of which was to hide the theft. The stolen fuel was sold to various commercial enterprises in the region. The revenue was shared between all members of the community.

These crimes in the housing sector are due to the concealment by officials of bodies of state power and local self-government, law-enforcement and supervising bodies, representatives of management companies transmit a prearranged remuneration in return for their inaction.

A vivid example is the detention by employees of the Department to identify crimes in the sphere of housing and communal services №8 Uebipk GU MVD of Russia in Volgograd region Director of the HOA Dzerzhinsky district of Volgograd on suspicion of committing a crime under article 291 of the criminal code. G. proposed illegal monetary reward in the amount of 200 thousand rubles. security officer Uebipk GU MVD of Russia in the Volgograd region for the failure further checks of financial and economic activities TSZH. At the time of transfer of a bribe the suspect was detained by operative employees.

A typical scheme of criminal activity in the housing sector is the establishment of municipal institutions (on the basis of the decree of the head of municipal entity) engaged in the transfer of budgetary funds on capital repairs, and performs control functions for the development of these tools. The competence of this organization includes the functions of technical supervision and coordination of acts of acceptance of work performed. The founders of this organization are the authorities of the municipality, in charge of utilities. For each object overhaul is an agreement on the provision of subsidies for payment of major repairs.

However, by virtue of its structure, material and technical base, housing authorities forced to enter into agreements with contractors, which are extremely difficult to control and accounting. You should note that currently the total volume of fixed assets of the Russian Federation on the housing and utilities sector accounts for over $26 \%$ (approximately 8 trillion. RUB.); it includes objects in the amount of 19 million and a total area of 3 billion $\mathrm{m} 2$, they consumed over $20 \%$ of state energy resources. Payables to resource-supplying organizations is more than 350 billion rubles ${ }^{20}$. Referring to the emergency Fund, it should be said that the state today in value terms has 93 billion rubles Annually for the modernization of housing and communal services the state allocates significant amounts of funds (in billion rubles): 2009 figure should be 142.2; 2010. 223,2; 2011. - 216,5; 2012. - 136,0; 2013. - 104,2; 2014. - 144,5; 2015. - To 118.021 . Here is laid the Foundation for the implementation of criminal activities in this area.

Today activity in the housing sector can be characterized by the following negative trends in organizational and managerial problems and economic plan:

- a complex system of contractual relationships between the public, municipal authorities and management companies providing housing and communal services;

- low control over the activities of management companies from the municipal authorities and other regulatory bodies; 
- the creation of management companies with additional services and new legal entities for realization of complex of works in housing and communal services, which leads to the decentralization of functions and management;

- $\quad$ high level of criminal assault on the part of performers of contract works in housing and communal services.

The attractiveness of utilities to implement various kinds of criminal assault, namely: fraud, misappropriation or embezzlement, the creation and use of shell companies, criminal, bankruptcy, commercial bribery, bribery, misuse of state funds and other crimes, is a consequence of the existence of the negative trends described above.

\section{Conclusion}

The head of the municipal institution creates an independent commercial entities (companies), founded by his relatives or affiliates (trusted) person. Often the actual management of such organizations carries out the aforementioned head. In investigatory practice there were cases when for such purposes were purchased from existing organizations (companies) with economic and banking history. In some cases, took place the creation and registration of the HOA for dummies. The Russian legislation does not provide for HOA mandatory bidding when choosing the contractor, it shall be entitled to choose the Contracting organization. Or officials of the municipal administration and institutions, using its administrative resources, executives of the HOA homes located within their jurisdiction, to make a choice in favor of their subordinate organizations, citing a possible refusal of participation in the program. Example of committing such a crime we cited above.

\section{References}

The decree of the President of the Russian Federation dated 11.04.2014 No. 226. ATP ConsultantPlus. [Electronic resource].

Bychkov V.V. the Investigation of corruption crimes related to bribery : a training manual. - Chelyabinsk: Chelyabinsk law Institute of MIA of Russia, 2009.

Poleschuk, O.V., I. M. Shamratov Basic methods of investigation of legalization of proceeds of crime : scientific and practical guide. - M. : Yurlitinform, 2015.

Pimenov N.A. the problem of corruption in Russia // Russian justice. 2011. No. 5.

Official website of the General Prosecutor of the Russian Federation. [Electronic resource] URL : http://genproc.gov.ru/

The official website of the Ministry of internal Affairs of Russia. [Electronic resource] URL : https://mvd.ru

The Website "Corruption. no." [Electronic resource] URL : http://corrupcia.net/

Conclusion of the accounts chamber of the Russian Federation on the draft Federal laws "on the Federal budget for 2010-2014, and planning periods 2011-2016". The official website of the accounts chamber of the Russian Federation. 
[Electronic resource] URL: http://audit.gov.ru/ (accessed: 05.07.2015).

The official site of Prosecutor's office of Perm region. [Electronic resource] URL: http://prokuror.perm.ru/

Russian newspaper. [Electronic resource] URL: http://www.rg.ru/

The official website of the Investigative Committee of the Russian Federation. [Electronic resource] URL: http://sledcom.ru/

On approval of Instructions on filling forms of Federal statistical observation №22-housing and communal services (summary) "Information about the work of housing and communal organizations in the conditions of reform": the order of Rosstat from 22.12.2014 No. 719. ATP ConsultantPlus. [Electronic resource] URL: http://base.consultant.ru/

GOST R 51617-2000. State standard of the Russian Federation. Housing and communal services. General technical conditions. (appr. By the resolution of Gosstandart of Russia from 19.06.2000 N 158-CT).

Housing code of the Russian Federation: paragraph 2 of article 161 of the Federal law of 29.12.2004 №188-FZ (red. ot on 29.06.2015). ATP ConsultantPlus. [Electronic resource] URL: http://www.consultant.ru/

Website "Real housing". 24.10.2013. [Electronic resource] URL: http://real-gkh.ru/

Zui I. I. About the effectiveness of law enforcement agencies in the detection, suppression and investigation of crimes related to misuse of financial resources in housing and communal services // Actual questions of organization of activity of internal Affairs agencies on the identification, prevention, disclosure and investigation of crimes in the sphere of housing and utilities: a collection of articles all-Russian scientific-practical conference - Moscow: Academy of Ministry of interior of Russia, on 29 March 2013, P.25-26.

About provision of utilities to owners and users of premises in apartment buildings and residential houses (together with "Rules of granting of utilities to proprietors and users of premises in apartment buildings and residential houses"): the Resolution of the Government of the Russian Federation of 06.05.2011 №354 (edited on 14.02.2015). ATP ConsultantPlus. [Electronic resource] URL: http:// www.consultant.ru/

GOST R 51617-2000. State standard of the Russian Federation. Housing and communal services. General technical conditions. (appr. By the resolution of Gosstandart of Russia from 19.06.2000 N 158-CT) (as amended from 22.07.2003).

\section{Endnote}

2. The official website of the Ministry of internal Affairs of Russia. [Electronic resource] URL: https://mvd.ru/

3. The decree of the President of the Russian Federation dated 11.04.2014 No. 226. ATP ConsultantPlus. [Electronic resource]. 
4. Poleschuk, O. V., I. M. Shamratov Basic methods of investigation of legalization of proceeds of crime : scientific and practical guide. - M. : Yurlitinform, 2015. P. 6.

5. Bychkov V. V. the Investigation of corruption crimes related to bribery : a training manual. - Chelyabinsk : Chelyabinsk law Institute of MIA of Russia, 2009. P.3

6. Official website of the General Prosecutor of the Russian Federation. [Electronic resource] URL : http://genproc.gov.ru/

7. Conclusion of the accounts chamber of the Russian Federation on the draft Federal laws "on the Federal budget for 2010-2014, and planning periods 20112016". The official website of the accounts chamber of the Russian Federation. [Electronic resource] URL: http://audit.gov.ru/ (accessed: 05.07.2015).

8. The fight against bribery in the Perm region. 25.12.2014. The official site of Prosecutor's office of Perm region. [Electronic resource] URL: http://prokuror. perm.ru/inspections/im-c/2014/12/25/97/ (accessed on 10.10.2015).

9. The former Vice-mayor of Chebarkul impute commercial bribery. 18.02.2015. Russian newspaper. [Electronic resource] URL: http://www.rg.ru/2015/02/18/ reg-urfo/safonov-anons.html (11.10.2015).

10. In the Kaliningrad region, the head of Department on reforming of housing and communal services of a city administration of Sovetsk is suspected of taking bribes in large size. 17.06.2011. Official website of the Investigative Committee of the Russian Federation. [Electronic resource] URL: http://sledcom.ru/news/ item/556272/ (accessed on 10.10.2015)

11. On approval of Instructions on filling forms of Federal statistical observation №22-housing and communal services (summary) "Information about the work of housing and communal organizations in the conditions of reform": the order of Rosstat from 22.12.2014No. 719.ATPConsultantPlus. [Electronic resource] URL: http://base.consultant.ru/cons/cgi/online.cgi?req=doc;base=LAW;n=173895 (reference date: 14.04.2015).

12. GOST R 51617-2000. State standard of the Russian Federation. Housing and communal services. General technical conditions. (appr. By the resolution of Gosstandart of Russia from 19.06.2000 N 158-CT) (as amended from 22.07.2003).

13. In the Ulyanovsk region the sentence concerning members of an organized criminal group, illegally used public property. 11.08.2008. The official website of the Ministry of internal Affairs of Russia. [Electronic resource] URL: https:// mvd.ru/news/item/190874/ (accessed 27.06.2013)

14. The results of the fight against corruption in Mordovia. 20.01.2011. The official website of the Ministry of internal Affairs of Russia. [Electronic resource] URL: https://mvd.ru/news/item/175150 (11.04.2015)

15. Housing code of the Russian Federation: paragraph 2 of article 161 of the Federal law of 29.12.2004 №188-FZ (red. ot on 29.06.2015). ATP ConsultantPlus. [Electronic resource] URL: http://www.consultant.ru/popular/housing/ (accessed: 09.07.2015).

16. Every sixth applicant complained to the President of the Russian Federation on the system of housing and communal services Sergey Ivanov // Website "Real housing”. 24.10.2013. [Electronic resource] URL: http://real-gkh.ru/news/ kazhdyy-shestoy-obrativshiysya-zhaluetsya-prezidentu-rf-na-sistemu-zhkkhsergey-ivanov/ (accessed: 19.02.2014). 
17. GOST R 51617-2000. State standard of the Russian Federation. Housing and communal services. General technical conditions. (appr. By the resolution of Gosstandart of Russia from 19.06.2000 N 158-CT) (as amended from 22.07.2003).

18. In the Khanty-Mansi Autonomous district Prosecutor's office sent to court a criminal case against Deputy head of the urban settlement, Polish / the Official website of the Prosecutor General of the Russian Federation. [Electronic resource] URL: http://genproc.gov.ru/smi/news/archive/news-83704/ (accessed: 12.05.2014).

19. About provision of utilities to owners and users of premises in apartment buildings and residential houses (together with "Rules of granting of utilities to proprietors and users of premises in apartment buildings and residential houses"): the Resolution of the Government of the Russian Federation of 06.05.2011 №354 (edited on 14.02.2015). ATP ConsultantPlus. [Electronic resource] URL: http:// www.consultant.ru/document/cons_doc_LAW_175645/(accessed: 10.07.2015).

20. Zui I. I. About the effectiveness of law enforcement agencies in the detection, suppression and investigation of crimes related to misuse of financial resources in housing and communal services // Actual questions of organization of activity of internal Affairs agencies on the identification, prevention, disclosure and investigation of crimes in the sphere of housing and utilities: a collection of articles all-Russian scientific-practical conference - Moscow: Academy of Ministry of interior of Russia, on 29 March 2013, P.25-26.

21. The official website of the accounts chamber of the Russian Federation. [Electronic resource] URL: http://audit.gov.ru/ (accessed: 05.07.2015). 